\title{
Weed Management in Ginger (Zingiber officinale Roscoe) through Integrated Approaches
}

\author{
Dinesh Sah", P. Heisnam, N.K. Mahato and A.K. Pandey \\ All India Coordinated Research Project on Weed Management, College of Horticulture and \\ Forestry, Central Agricultural University, Pasighat-791102, Arunachal Pradesh, India \\ *Corresponding author
}

\section{A B S T R A C T}

\begin{tabular}{|c|}
\hline Keywords \\
\hline $\begin{array}{l}\text { Integrated weed } \\
\text { management, Mulch, } \\
\text { Pendimethalin, } \\
\text { Oxyfluorfen, } \\
\text { Glyphosate, Ginger, } \\
\text { Yield. }\end{array}$ \\
\hline Article Info \\
\hline $\begin{array}{l}\text { Accepted: } \\
17 \text { September } 2017 \\
\text { Available Online: } \\
10 \text { October } 2017\end{array}$ \\
\hline
\end{tabular}

Ginger (Zingiber officinale Roscoe) is grown in tropical and subtropical regions of the world for its spice and medicinal values. The emergence and early growth of ginger is inherently slow and weed growth can impact on yield. It has slow initial growth rate and shallow root system. As a result, it is invaded by a variety of weeds. A field experiment was carried out during 2015-16 and 2016-17 in randomized block design with three replications under AICRP on Weed Management at College of Horticulture and Forestry, CAU, Pasighat, Arunachal Pradesh, India with nine treatments. The experiment was conducted to identify an alternative to suppress weeds, enhance yield and income of small ginger farmers. Results showed that hand weeding twice recorded lowest weed density, dry weight of weeds, highest weed control efficiency, fresh rhizome yield (9.4 and 9.8 t/ha) and B:C ratio (1.7 and 2.0) during both the years. Among herbicidal weed control, integration of one hand weeding followed by mulching with pendimethaline @ $1.50 \mathrm{~kg}$ ai/ha and/ or oxyfluorfen@ $0.20 \mathrm{~kg}$ ai/ha proved effective in controlling weeds with higher fresh rhizome yield and BCR.

\section{Introduction}

Ginger (Zingiber officinale Roscoe) is grown in tropical and subtropical regions of the world for its spice and medicinal values, since time immemorial. India is a leading ginger producer in the world. The area under cultivation in India is 104.54 thousand ha and the total production of the country is 655.10 thousand tons (Das, 2016). Ginger is the main cash crop supporting the livelihood and improving the economic level of many ginger growers of North Eastern Region. Ginger is grown in almost all the states of the region but the leading states are Meghalaya, Mizoram, Arunachal Pradesh and Sikkim (Yadav et al.,
2004). About 3 lakhs tonnes of ginger are being produced annually from 47,641 ha land (Das, 2016). Most of ginger in North Eastern Hill states is produced under organic conditions. In NEHR, the production of ginger is highest in Meghalaya followed by Arunachal Pradesh and Nagaland.

As the crop is slow in sprouting and long duration, thus yield loss as a result of weed competition is expected to be tremendous. Weeds compete with ginger for nutrients, moisture and space and cause $35-75 \%$ yield reduction. The environmental condition of 
north eastern region is characterized by high temperature and rainfall which is highly conducive for year round emergence and growth of highly competitive perennial and annual weed species such as Cynodon spp., Cyprus spp., Digitaria spp., Commelina spp., Bidens pilosa, Ageratum conyzoides etc. In spite of the divers and highly competitive weed flora existing in the ginger growing areas, research information on ginger weed management is quite meager. Weeds cause reduction in crop yield and require extra cost in the total labour use in crop production. Akobunda (1987) reported that weeds result in $65 \%$ reduction in yield of root and tuber crops and takes $25 \%$ of total labor use in production. Generally farmers start late weeding when crop has been suffered with weed competition or some time ginger fields may be left unweeded and as a result ginger yield obtained from farmers' fields has always been low. Ginger is a long durational crop (more than 240 days), therefore preemergence application of herbicides alone does not control weeds throughout critical crop weed competition period of the crop and needs an integration of post-emergence application of herbicide or inter-culture operation in combination with pre-emergence herbicide application. The objective of the present study was therefore, to identify appropriate weed management method for optimum growth and yield of ginger under North Eastern Region.

\section{Materials and Methods}

The field experiment was conducted during 2015 and 2016 at College of Horticulture and Forestry, Pasighat in randomized block design with three replications. The experimental soil was sandy loam, acidic ( $\mathrm{pH}$ 5.5), medium in available $\mathrm{N}(326 \mathrm{~kg} / \mathrm{ha})$, and high in available $\mathrm{P}(25.8 \mathrm{~kg} / \mathrm{ha})$ and $\mathrm{K}(276.4 \mathrm{~kg} / \mathrm{ha})$. The treatments consisted of $\mathrm{T}_{1}$-Pendimethalin @ $1.5 \mathrm{~kg} / \mathrm{ha}$ after planting, $\mathrm{T}_{2}$-Oxyfluorfen @
$0.20 \mathrm{~kg} / \mathrm{ha}$ after planting, $\mathrm{T}_{3}$ - Pendimethalin @ $1.5 \mathrm{~kg} / \mathrm{ha}$ after planting $f b$ hand weeding 30 DAP but before mulching, $\mathrm{T}_{4}$ - Oxyfluorfen @ $0.20 \mathrm{~kg} / \mathrm{ha}$ after planting $f b$ hand weeding 30 DAP but before mulching, $\mathrm{T}_{5}$ - Glyphosate @ $0.80 \mathrm{~kg} / \mathrm{ha}$ before sprout emergence, $\mathrm{T}_{6^{-}}$ Glyphosate @ $0.80 \mathrm{~kg} / \mathrm{ha}$ plus Pendimethalin @ $1.5 \mathrm{~kg} / \mathrm{ha}$ before sprout emergence, $\mathrm{T}_{7^{-}}$ Glyphosate@0.80 kg /ha plus Oxyfluorfen @ $0.20 \mathrm{~kg} / \mathrm{ha}$ before sprout emergence, $\mathrm{T}_{8^{-}}$ Hand weeding 30 and $60 \mathrm{DAP}, \mathrm{T}_{9^{-}} \mathrm{Un}^{-}$ weeded control.

Ginger variety 'Nadia' was planted on 30 June, 2015 and 4 April, 2016 in rows $30 \mathrm{~cm}$ apart using a seed rate of $2.0 \mathrm{t} / \mathrm{ha}$. The crop was fertilized with $60 \mathrm{~kg} \mathrm{~N}, 90 \mathrm{~kg} \mathrm{P}$ and 60 $\mathrm{kg} \mathrm{K} /$ ha through urea (46\%), single super phosphate $\left(16 \% \mathrm{P}_{2} \mathrm{O}_{5}\right)$ and muriate of potash $\left(\mathrm{K}_{2} \mathrm{O}\right)$, respectively, at the time of planting. The herbicides and intercultural operations were applied as per the treatments to different plots. Pendimethalin/oxyfluorfen were applied as pre- emergence, glyphosate as post emergence. Straw mulch was applied immediately after spray and hand weeding were done at 30 and/or 60 DAP as per treatment. Herbicides were applied with backpack knapsack sprayer using $600 \mathrm{~L}$ water per hectare. Mulching was done after the herbicides were sprayed on second day as per treatment. Care was taken to ensure uniform thickness of the mulch and coverage of whole area of the plot. The rest of the management practices were adopted in accordance with the recommended package of practices. Data on density and dry weight of weeds were recorded at 75 DAP. The weed count and dry weight data were subjected to square root transformation $\sqrt{ }(\mathrm{x}+0.5)$. When the leaves turned yellow and dry, the crop from net plots was harvested. The rhizomes were dug taking care that they were not cut or damaged, then cleaned to remove soil and weighed for fresh weight. Economics of the treatments was computed based on the prevalent market 
prices of the inputs used and rhizomes produced. The data for different parameters were statistically analyzed by following the standard statistical methods.

\section{Results and Discussion}

Field data revealed that weed flora of experimental plots were Cynodon dactylon, Digitaria sanguinalis, Panicum sp., Echinochloa spp., Eleusine indica, Cyperus spp., Commelina benghalensis, Murdania kiosak, Urena lobata, Ageratum conyzoids, Spilanthes acmella, Sida acuta, etc.

\section{Weed population, dry weight and weed control efficiency}

Data on weed population revealed that population of grassy and sedge weeds were high in the experimental field and it was observed that maximum weed population recorded in the un-weeded control plots. Keeping the plots weed free upto 60 days after planting (DAP) significantly reduced the weed population. Application of oxyfluorfen supplemented with hand weeding at 30 days after planting (DAP) $f b$ mulching was also found effective treatment for controlling weeds (Table 1) during both the cropping season. This may be due to the longer period of persistence of oxyfluorfen in soil (Pillai et al., 2015).

Data recorded during both the cropping season on weed dry matter production revealed that hand weeding at 30 and 60 DAP reduced weed dry matter production $(2.7 \mathrm{~g}$ and $3.6 \mathrm{~g} / \mathrm{m}^{2}$ ) and increase weed control efficiency (75.2 and 77.6\%). Application of oxyfluorfen supplemented with hand weeding at $30 \mathrm{DAP}$ fb mulching showed a reduction in weed dry weight and increased WCE (59.4 and $72.9 \%$ ). The highest weed dry weight was recorded under un-weeded control. All weed control treatments expressed significant influence on weed dry weight and weed control efficiency (Table 1). The dry weight of weeds in plot treated by oxyfluorfen @ $0.20 \mathrm{~kg} / \mathrm{ha}$ supplemented with hand weeding at 30 DAP $f b$ mulching was $3.4 \mathrm{~g} / \mathrm{m}^{2}$ in the first season and $4.0 \mathrm{~g} / \mathrm{m}^{2}$ in the second season, which was significantly lower than other weed control treatments except two hand weeding treatment. These results clearly indicates that biomass of the weeds varied from season to season. Data indicated that application of oxyfluorfen @ $0.20 \mathrm{~kg} / \mathrm{ha}$ supplemented with hand weeding at 30 DAP $f b$ mulching gave the minimum weed population and weed biomass that gave the highest weed control efficiency (WCE) compared with un-weeded check during both the years. Sathya Priya et al., (2013) recorded lesser weed density and dry weight with preemergence application of oxyfluorfen (23.5per cent EC) $200 \mathrm{~g} / \mathrm{ha}$ in onion. Weed control efficiency which indicates the comparative magnitude of reduction in weed dry matter was highly influenced by different weed control treatments.

Weed control efficiency was maximum (75.2 and 77.6 per cent) with hand weeding 30 and 60 DAP, followed by oxyfluorfen@0.20 $\mathrm{kg} / \mathrm{ha}$ after planting supplemented with hand weeding 30 DAP $f b$ mulching during both the years. Kaur et al., $(2008,2016)$ also reported effective and long-term control of weeds with integration of herbicide and straw mulch in turmeric.

\section{Effect on crops}

\section{Crop growth parameters}

The results revealed that all the weed control treatments significantly influenced tillers per plant and plant height (Table 2). The maximum number of tillers per plant (3.2 and $7.5)$ and plant height $(56.2 \mathrm{~cm}$ and $52.3 \mathrm{~cm})$ were recorded in hand weeded plots twice at 
30 DAP and 60 DAP during both the years. Un-weeded control plot gave minimum number of tillers per plant and minimum plant height followed by pre emergence application of pendimethaline in couple with one hand weeding $f b$ mulching. All weed control measures exhibited higher number of tillers and plant height than un-weeded control. This might be due to early emergence of plants under weed free and mulched conditions which have favored growth in terms of plant height and number of tillers. Favorable soil temperature and more available soil moisture for crop growth may also be responsible for maximum tiller and plant height in mulched plots.

Table.1 Effect of integrated weed management practices on weed population (no. $/ \mathrm{m}^{2}$ )

\begin{tabular}{|c|c|c|c|c|c|c|c|c|c|c|}
\hline \multirow[t]{2}{*}{ Treatments } & \multicolumn{2}{|c|}{$\begin{array}{l}\text { Grassy and sedge } \\
\text { weeds }\left(\text { no. } / \mathrm{m}^{2}\right)\end{array}$} & \multicolumn{2}{|c|}{$\begin{array}{l}\text { Broad leaved } \\
\text { weeds }\left(\text { no. } / \mathrm{m}^{2}\right)\end{array}$} & \multicolumn{2}{|c|}{ Total weeds $\left(\right.$ no. $\left./ \mathrm{m}^{2}\right)$} & \multicolumn{2}{|c|}{$\begin{array}{l}\text { Weed dry matter } \\
\left(\mathrm{g} / \mathrm{m}^{2}\right)\end{array}$} & \multicolumn{2}{|c|}{ WCE (\%) } \\
\hline & 2015 & 2016 & 2015 & 2016 & 2015 & 2016 & 2015 & 2016 & 2015 & 2016 \\
\hline $\mathrm{T}_{1}$ & $\begin{array}{c}8.9 \\
(80.3)\end{array}$ & $\begin{array}{c}12.41 \\
(153.7)\end{array}$ & $\begin{array}{c}6.1 \\
(36.7)\end{array}$ & $9.2(84.7)$ & $\begin{array}{c}10.8 \\
(117.1) \\
\end{array}$ & $\begin{array}{c}15.4 \\
(238.3)\end{array}$ & $\begin{array}{l}4.5 \\
(19.7)\end{array}$ & $\begin{array}{l}6.2 \\
(34.8) \\
\end{array}$ & 27.9 & 32.8 \\
\hline $\mathrm{T}_{2}$ & $\begin{array}{c}8.6 \\
(73.2)\end{array}$ & $\begin{array}{l}11.58 \\
(130)\end{array}$ & $\begin{array}{c}5.8 \\
(33.8)\end{array}$ & $6.7(44.7)$ & $\begin{array}{l}10.3 \\
(107)\end{array}$ & $\begin{array}{c}13.2 \\
(174.7) \\
\end{array}$ & $\begin{array}{l}4.2 \\
(16.9)\end{array}$ & $\begin{array}{l}5.3 \\
(30.2) \\
\end{array}$ & 38.2 & 50.8 \\
\hline $\mathrm{T}_{3}$ & $\begin{array}{c}7.8 \\
(61.3) \\
\end{array}$ & $\begin{array}{c}10.72 \\
(112.3) \\
\end{array}$ & $\begin{array}{c}5.2 \\
(27.7)\end{array}$ & $\begin{array}{r}7.2 \\
(52) \\
\end{array}$ & $9.4(88.9)$ & $\begin{array}{c}12.7 \\
(164.3) \\
\end{array}$ & $\begin{array}{l}3.8 \\
(14.3)\end{array}$ & $\begin{array}{l}5.2 \\
(26.6) \\
\end{array}$ & 47.8 & 53.9 \\
\hline $\mathrm{T}_{4}$ & $\begin{array}{c}7.2 \\
(51.3)\end{array}$ & $\begin{array}{c}8.29 \\
(64.7)\end{array}$ & $\begin{array}{c}4.4 \\
(19.2)\end{array}$ & $5.4(28.7)$ & $8.4(70.5)$ & $\begin{array}{c}10.4 \\
(110.7)\end{array}$ & $\begin{array}{l}3.4 \\
(11.1)\end{array}$ & $\begin{array}{l}4.0 \\
(25.4)\end{array}$ & 59.4 & 72.9 \\
\hline $\mathrm{T}_{5}$ & $\begin{array}{c}8.4 \\
(71.2)\end{array}$ & $\begin{array}{c}11.53 \\
(128.7)\end{array}$ & $\begin{array}{c}6.4 \\
(41.1)\end{array}$ & $\begin{array}{c}8.7 \\
(76)\end{array}$ & $\begin{array}{c}10.6 \\
(112.3)\end{array}$ & $\begin{array}{c}14.3 \\
(204.7)\end{array}$ & $\begin{array}{l}4.1 \\
(16.1)\end{array}$ & $\begin{array}{l}5.7 \\
(33.5)\end{array}$ & 41.2 & 43.1 \\
\hline $\mathrm{T}_{6}$ & $\begin{array}{c}8.3 \\
(68.3) \\
\end{array}$ & $\begin{array}{c}11.29 \\
(123.7) \\
\end{array}$ & $6(35.6)$ & $7.7(60.3)$ & $\begin{array}{c}10.2 \\
(104)\end{array}$ & $\begin{array}{c}13.6 \\
(184) \\
\end{array}$ & $\begin{array}{l}4.0 \\
(15.5) \\
\end{array}$ & $\begin{array}{l}5.5 \\
(28.1) \\
\end{array}$ & 43.4 & 48.2 \\
\hline $\mathrm{T} 7$ & $\begin{array}{c}7.0 \\
(59.2)\end{array}$ & $\begin{array}{c}9.34 \\
(83.3)\end{array}$ & $\begin{array}{l}5.0 \\
(25)\end{array}$ & $6.9(47.3)$ & $9.2(84.2)$ & $\begin{array}{c}11.4 \\
(130.7)\end{array}$ & $\begin{array}{l}3.7 \\
(13.2)\end{array}$ & $\begin{array}{l}5.7 \\
(26.3)\end{array}$ & 51.6 & 62.3 \\
\hline $\mathrm{T}_{8}$ & $\begin{array}{c}5.5 \\
(30.1)\end{array}$ & $\begin{array}{c}7.79 \\
(56.7)\end{array}$ & $\begin{array}{c}4.3 \\
(18.2)\end{array}$ & $4.3(19.3)$ & $6.9(48.4)$ & $\begin{array}{c}8.5 \\
(72) \\
\end{array}$ & $\begin{array}{l}2.7 \\
(6.8)\end{array}$ & $\begin{array}{l}3.6 \\
(21.7) \\
\end{array}$ & 75.2 & 77.6 \\
\hline $\mathrm{T}_{9}$ & $\begin{array}{c}9.7 \\
(93.3)\end{array}$ & $\begin{array}{c}15.38 \\
(232.7) \\
\end{array}$ & $\begin{array}{c}6.8 \\
(46.4) \\
\end{array}$ & $\begin{array}{c}10.3 \\
(105.7) \\
\end{array}$ & $\begin{array}{c}11.8 \\
(139.7) \\
\end{array}$ & $\begin{array}{c}18.4 \\
(338.3) \\
\end{array}$ & $\begin{array}{l}5.3 \\
(27.4)\end{array}$ & $\begin{array}{l}7.6 \\
(35.9) \\
\end{array}$ & 00 & 00 \\
\hline SEm \pm & 0.11 & 0.47 & 0.10 & 0.39 & 0.10 & 0.60 & 0.03 & 0.19 & 0.55 & 3.17 \\
\hline $\operatorname{LSD}(\mathrm{P}=0.05)$ & 0.32 & 0.81 & 0.31 & 1.17 & 0.30 & 1.80 & 0.10 & 0.58 & 1.66 & 9.51 \\
\hline
\end{tabular}

Figures in the parentheses indicate the actual values, Transformed value $=\sqrt{ }(x+0.5)$

Table.2 Effect of integrated weed management practices on growth and yield attributes of ginger

\begin{tabular}{|l|c|c|c|c|c|c|c|c|c|c|}
\hline \multirow{2}{*}{ Treatments } & \multicolumn{2}{|l|}{$\begin{array}{l}\text { No. of tillers/ } \\
\text { plant }\end{array}$} & \multicolumn{2}{|c|}{ Plant height $\mathbf{( c m )}$} & \multicolumn{2}{c|}{$\begin{array}{l}\text { Rhizome length } \\
\text { (cm) }\end{array}$} & \multicolumn{2}{c|}{$\begin{array}{c}\text { Rhizome } \\
\text { width (cm) }\end{array}$} & \multicolumn{2}{c|}{$\begin{array}{c}\text { No. of } \\
\text { fingers/rhizome }\end{array}$} \\
\cline { 2 - 12 } & $\mathbf{2 0 1 5}$ & $\mathbf{2 0 1 6}$ & $\mathbf{2 0 1 5}$ & $\mathbf{2 0 1 5}$ & $\mathbf{2 0 1 5}$ & $\mathbf{2 0 1 6}$ & $\mathbf{2 0 1 5}$ & $\mathbf{2 0 1 6}$ & $\mathbf{2 0 1 5}$ & $\mathbf{2 0 1 6}$ \\
\hline $\mathrm{T}_{1}$ & 1.9 & 6.7 & 51.7 & 50.2 & 6.1 & 5.9 & 4.3 & 4.4 & 2.4 & 4.5 \\
\hline $\mathrm{T}_{2}$ & 2.8 & 6.3 & 50.2 & 48.8 & 7.2 & 6.6 & 4.9 & 5.0 & 3.0 & 5.2 \\
\hline $\mathrm{T}_{3}$ & 2.9 & 7.2 & 53.5 & 51.1 & 7.9 & 6.6 & 5.2 & 5.1 & 3.2 & 5.3 \\
\hline $\mathrm{T}_{4}$ & 2.6 & 5.7 & 48.2 & 46.5 & 6.6 & 6.8 & 4.7 & 5.3 & 2.9 & 5.5 \\
\hline $\mathrm{T}_{5}$ & 2.2 & 6.7 & 51.2 & 49.8 & 6.4 & 6.2 & 4.6 & 4.5 & 2.5 & 4.7 \\
\hline $\mathrm{T}_{6}$ & 2.5 & 7.2 & 52.5 & 50.7 & 6.5 & 6.2 & 4.7 & 4.6 & 2.8 & 5 \\
\hline $\mathrm{T}_{7}$ & 2.3 & 5.3 & 47.5 & 39.9 & 6.6 & 6.3 & 4.7 & 4.7 & 2.7 & 4.7 \\
\hline $\mathrm{T}_{8}$ & 3.2 & 7.5 & 56.2 & 52.3 & 8.4 & 6.9 & 5.5 & 5.7 & 3.4 & 4.2 \\
\hline $\mathrm{T}_{9}$ & 1.5 & 2.7 & 44.7 & 32 & 5.7 & 5.2 & 3.9 & 4.0 & 2.1 & 3.8 \\
\hline $\mathrm{SEm} \pm$ & 0.07 & 1.19 & 3.1 & 4.7 & 0.31 & 0.53 & 0.24 & 0.28 & 0.19 & 0.38 \\
\hline $\mathrm{LSD}(\mathrm{P}=0.05)$ & 0.04 & 0.69 & 1.80 & 2.71 & 0.94 & 1.59 & 0.71 & 0.84 & 0.57 & 1.13 \\
\hline
\end{tabular}


Table.3 Effect of integrated weed management practices on economics of ginger production

\begin{tabular}{|l|c|c|c|c|}
\hline \multirow{2}{*}{ Treatments } & \multicolumn{2}{|c|}{ Fresh rhizome yield (t/ha) } & \multicolumn{2}{c|}{ BCR } \\
\cline { 2 - 5 } & $\mathbf{2 0 1 5}$ & $\mathbf{2 0 1 6}$ & $\mathbf{2 0 1 5}$ & $\mathbf{2 0 1 6}$ \\
\hline $\mathbf{T}_{\mathbf{1}}$ & 8.1 & 8.3 & 1.6 & 1.7 \\
\hline $\mathbf{T}_{\mathbf{2}}$ & 8.9 & 9.1 & 1.7 & 1.8 \\
\hline $\mathbf{T}_{\mathbf{3}}$ & 9.2 & 9.2 & 1.7 & 1.9 \\
\hline $\mathbf{T}_{\mathbf{4}}$ & 8.8 & 9.3 & 1.6 & 1.9 \\
\hline $\mathbf{T}_{\mathbf{5}}$ & 8.7 & 8.9 & 1.7 & 1.8 \\
\hline $\mathbf{T}_{\mathbf{6}}$ & 8.7 & 9.0 & 1.7 & 1.8 \\
\hline $\mathbf{T 7}^{\mathbf{T}}$ & 8.7 & 8.9 & 1.7 & 1.8 \\
\hline $\mathbf{T}_{\mathbf{8}}$ & 9.4 & 9.8 & 1.7 & 2.0 \\
\hline $\mathbf{T}_{\mathbf{9}}$ & 6.2 & 5.8 & 1.2 & 1.2 \\
\hline SEm $\mathbf{E}$ & 0.25 & 0.23 & -- & -- \\
\hline $\mathbf{L S D}(\mathbf{P}=\mathbf{0 . 0 5})$ & 0.76 & 0.7 & -- & -- \\
\hline
\end{tabular}

General cost of cultivation Rs. 74000/ha, Cost of weed management practices is additional.

Table.4 Correlation of weed density, weed dry weight, weed control efficiency and number of fingers /rhizome with fresh rhizome yield of ginger

\begin{tabular}{|l|l|l|}
\hline \multirow{2}{*}{ Variables } & \multicolumn{2}{|c|}{ Fresh Rhizome yield } \\
\cline { 2 - 3 } & $\mathbf{2 0 1 5}$ & $\mathbf{2 0 1 6}$ \\
\hline Weed density $\left(\mathrm{m}^{2}\right)$ & $-0.727^{*}$ & $-0.864^{*}$ \\
\hline Weed dry weight $\left(\mathrm{g} / \mathrm{m}^{2}\right)$ & $-0.852^{*}$ & $-0.879^{*}$ \\
\hline Weed control efficiency $(\%)$ & $0.898^{*}$ & $0.927^{*}$ \\
\hline Number of fingers /rhizome & $0.858^{*}$ & $0.633^{\mathrm{NS}}$ \\
\hline
\end{tabular}

*Significant at 5\%, NS-Non significant

\section{Yield attributes and yields of ginger}

Hand weeding twice at $30 \mathrm{DAP}$ and 60 DAP resulted in significantly higher length and width of rhizome during both the year which was close to application of pendimethalin@ $1.5 \mathrm{~kg} / \mathrm{ha}$ supplemented with one hand weeding at 30 DAP $f b$ mulching during first year and with oxyfluorfen @ $0.20 \mathrm{~kg} / \mathrm{ha}$ supplemented with one hand weeding at 30 DAP $f b$ mulching during second year. Whereas, in case of number of rhizomes per finger recorded maximum (3.4) in hand weeded plot during first year and 5.5 in plot treated with oxyfluorfen $0.20 \mathrm{~kg} / \mathrm{ha}$ supplemented with one hand weeding at 30 DAP $f b$ mulching during second year. Hand weeding twice at $30 \mathrm{DAP}$ and $60 \mathrm{DAP}$ resulted in significantly higher number of fingers per rhizome which was at par with application of oxyfluorfen alone $f b$ mulching, pendimethalin supplemented with one hand weeding at 30 DAP $f b$ mulching, oxyfluorfen supplemented with one hand weeding at 30 DAP $f b$ mulching and glyphosate + pendimethalin during first year (Table 2). During second year of experimentation, application of oxyfluorfen $0.20 \mathrm{~kg} / \mathrm{ha}$ supplemented with one hand weeding at 30 DAP $f b$ mulching $\left(\mathrm{T}_{4}\right)$ proved superior in production of finger /rhizome and it was at par with pre-emergence application of pendimethalin@ $1.5 \mathrm{~kg} / \mathrm{ha}$ after planting $f b$ hand weeding 30 DAP but before mulching $\left(\mathrm{T}_{3}\right)$, oxyfluorfen @ 0.20kg/ha after planting $\left(\mathrm{T}_{2}\right)$, glyphosate @ $0.80 \mathrm{~kg} / \mathrm{ha}+$ 
pendimethalin @ $1.5 \mathrm{~kg} / \mathrm{ha}$ before sprout emergence $\left(\mathrm{T}_{6}\right)$, glyphosate @ $0.80 \mathrm{~kg} / \mathrm{ha}$ before sprout emergence $\left(\mathrm{T}_{5}\right)$, glyphosate @ $0.80 \mathrm{~kg} / \mathrm{ha}+$ oxyfluorfen @ $0.20 \mathrm{~kg} / \mathrm{ha}$ before sprout emergence $\left(\mathrm{T}_{7}\right)$ and pendimethalin@1.5 kg/ha after planting $\left(\mathrm{T}_{1}\right)$. This is attributed with better control of weeds. Further, timely and effective control of weeds is expected to have better availability of moisture, nutrients, and solar radiation to the crop plants, thereby increasing photosynthetic rate, leading to higher supply of carbohydrates which resulted in higher increase in yield attributes than unweeded control. On contrary to this, uncontrolled weed growth throughout the cropping season in weedy check plots arrested the crop growth due to severe crop-weed competition.

All the weed control treatments differed in influencing fresh rhizome yield of ginger. Hand weeding twice at 30 DAP and 60 DAP recorded significantly higher fresh rhizome yield (9.4 and $9.8 \mathrm{t} / \mathrm{ha})$. It was statistically at par with remaining other weed control treatments (Table 3) during both the years. Two hand weeding treatments provided the season long weed free condition and hence resulted in appreciably higher yield than other treatments. Pre-emergence application of pendimethalin @ $1.5 \mathrm{~kg} / \mathrm{ha}$ after planting coupled with hand weeding 30 DAP $\mathrm{fb}$ mulching $\left(\mathrm{T}_{3}\right)$ and oxyfluorfen @ $0.20 \mathrm{~kg} / \mathrm{ha}$ coupled with hand weeding 30 DAP fb mulching $\left(\mathrm{T}_{4}\right)$ were the next superior treatments with respect to fresh rhizome yield, as they improved the rhizome yield to the tune of 48.4, 58.2 and 41.9, 60.3 per cent over the weedy check. These treatments kept the crop almost weed free up to 75 days that markedly reduced the competition for nutrients and other resources by weeds which ultimately reduced weed dry matter production and nutrient depletion. Furthermore, the most severe competition throughout the cropping season due to unstricted weed growth in weedy check plots led to enhanced nutrient removal and moisture by weeds; thereby adversely affecting the crop growth and yield. Krishnamurthy and Ayyaswamy (2000) reported $75 \%$ reduction in the yield of turmeric due to season long competition with weeds.

Weed density and weed dry weight remained negatively correlated with fresh rhizome yield of ginger during both the year (Table 4), indicating that the weeds had negative influence on fresh rhizome yield. In present study, weed dry weight was closely correlated followed by weed density during both the years. The closest relationship of fresh rhizome yield with weed dry weight was observed $-0.852 \&-0.879$ followed by weed density. Significant and positive correlation was observed in fresh rhizome yield with WCE during both the years and with number of finger/rhizome during first year. This indicates that weed dry weight and WCE is more accurate parameter to estimate the reduction and/or enhancement in fresh rhizome yield as compared to weed density.

\section{Economic analysis}

The benefit: cost ratio (BCR) under different treatments varied from 1.60-2.00 as compared to 1.20 under weedy check. During first year of experimentation maximum benefit cost ratio 1.7 was associated with treatment two hand weeding $\left(\mathrm{T}_{8}\right)$, pendimethalin@1.5 kg/ha after planting $f b$ hand weeding 30 DAP but before mulching $\left(\mathrm{T}_{3}\right)$, oxyfluorfen @ 0.20kg/ha after planting $\left(\mathrm{T}_{2}\right)$, glyphosate @ $0.80 \mathrm{~kg} / \mathrm{ha}$ plus pendimethalin@ @ $1.5 \mathrm{~kg} / \mathrm{ha}$ before sprout emergence $\left(\mathrm{T}_{6}\right)$, glyphosate @ $0.80 \mathrm{~kg} / \mathrm{ha}$ before sprout emergence $\left(\mathrm{T}_{5}\right)$, glyphosate @ $0.80 \mathrm{~kg} / \mathrm{ha}$ plus oxyfluorfen @ $0.20 \mathrm{~kg} / \mathrm{ha}$ before sprout emergence $\left(\mathrm{T}_{7}\right)$. and during second year maximum BCR 2.0 was with two 
hand weeding $\left(\mathrm{T}_{8}\right), 1.9$ with oxyfluorfen supplemented with one hand weeding at 30 DAP fb mulching $\left(\mathrm{T}_{4}\right)$ and pendimethalin @ $1.5 \mathrm{~kg} / \mathrm{ha}$ after planting $f b$ hand weeding 30 DAP but before mulching $\left(\mathrm{T}_{3}\right)$. Hand weeding showed superiority over other treatments during both the years. The benefit cost ratio (BCR) was higher during second year in comparison to first year might be due to higher rhizome yield during second year of experimentation (Table 3). Amongst the weed-control treatments, hand-weeding incurred the highest cost of production when compared with rest of the treatment. Preemergence application of pendimethalin @ $1.5 \mathrm{~kg} / \mathrm{ha}$ after planting coupled with hand weeding 30 DAP fb mulching $\left(\mathrm{T}_{3}\right)$ and oxyfluorfen@0.20 kg/ha coupled with hand weeding $30 \mathrm{DAP} f b$ mulching $\left(\mathrm{T}_{4}\right)$ were the next superior treatments with respect to BCR. Better growth and yield attributes were reflected in achieving higher rhizome yield under these three treatments provide higher benefit cost ratio (AR of Jorhat, 2015).

\section{References}

Akobundu, I.O., 1987. Weed Science in the tropics; Principles and Practices. A Wiley- Inter science Publications. pp. 71-105.

Annual Report, AICRP-WM, 2014-15. All India Coordinated Research Project on Weed Management, AAU, Jorhat centre, Assam pp.6 \& 53.

Das. Kalyan, 2016. Production conditions of spices in North east India: cases of ginger and chilli. National research programme on plantation development Discussion paper no.54.

Kaur, K., Bhullar, M.S., Kaur, J. and Walia, U.S. 2008. Weed management in turmeric (Curcuma longa) through integrated approaches. Indian Journal of Agronomy 53(3): 224-229.

Kaur, N., Gill, R I S and Bhullar, M S. 2016. Integrated weed management in poplar (Populus deltoides)-turmeric (Curcuma longa) based agroforestry system in Punjab. Indian Journal of Agronomy 61 (2): 168-173.

Krishnamurthy, V.V., and Ayyaswamy M. 2000. Effect of herbicides on yield of turmeric. Spice India 13: 9-11.

Pillai, Asha V., Joseph, P. A. and Abraham, C. T., 2015. Integrated weed management in ginger. Proceedings of 25th Asian-Pacific Weed Science Society Conference on Weed Science for Sustainable Agriculture, Environment and Biodiversity, Hyderabad, India 13-16 October, 2015.p.390.

Sathya Priya, R., Chinnusamy C., Manickasundaram P., Murali A. P. 2013. Evaluation of new formulation of oxyfluorfen $(23.5 \%$ EC) for weed control efficacy and bulb yield in onion. American Journal of Plant Sciences 4, 890-895.

Yadav, R.K., Yadav, D.S., Rai, N., Sanwal, S K. and Sarma, P. 2004. Commercial prospects of ginger cultivation in NorthEastern Region. ENVIS Bulletin: Himalayan Ecology Vol. 12(2).

\section{How to cite this article:}

Dinesh Sah, P. Heisnam, N.K. Mahato and Pandey, A.K. 2017. Weed Management in Ginger (Zingiber officinale Roscoe) through Integrated Approaches. Int.J.Curr.Microbiol.App.Sci. 6(10): 1839-1845. doi: https://doi.org/10.20546/ijcmas.2017.610.222 